\title{
МЕТОДИКА ИНТЕГРАЛЬНОЙ ОЦЕНКИ ТРАНСФОРМАЦИЙ ВОДНЫХ ЭКОСИСТЕМ
}

\author{
Е. В. Беспалова \\ Воронежский государственный университет, Россия
}

Поступила в редакцию 2 июля 2018 г.

\begin{abstract}
Аннотация: В статье приводятся результаты исследования неоплейстоценовых и современных водных экосистем центра Восточно-Европейской равнины, которые позволили выявить закономерности изменения таксономических пропорций в сообществах фитопланктона и микрофитобентоса при смене природных и природно-антропогенных условий и определить параметры экологической нормы их распределения. Выявленные связи между изменением эколого-биологических характеристик и природным и природно-антропогенным воздействием положены в основу методики интегральной оценки трансформаций водных экосистем. Количественно определены пороговые величины показателей водной экосистемы, отражающие ее переход из одного состояния в другое, а также изменение уровня нагрузки на нее. Проведена модернизация метода графического сопоставления таксономических пропорций в сообществах фитопланктона и микрофитобентоса, которая позволяет расширить область его применения.
\end{abstract}

Ключевые слова: интегральная оценка, водные экосистемы, трансформация, таксономическая структура, микроводоросли, цианобактерии, графический анализ.

Abstract: The results of a research of neopleistocene and modern water ecosystems of the center of the East European Plain are given. Regularities of change of taxonomical proportions in communities of phytoplankton and a microphytobenthos when changing natural and natural and anthropogenic conditions are revealed and parameters of environmental standard of their distribution are determined. The revealed communications between change of ecological and biological characteristics both natural and natural and anthropogenic influence are the basis for a technique of integrated assessment of transformations of water ecosystems. Threshold sizes of indicators of a water ecosystem are determined, they reflect its transition from one state to another and also change of level of load of it. Modernization of a method of graphic comparison of taxonomical proportions in communities of phytoplankton and a microphytobenthos is carried out that allows to expand the field of its application.

Key words: integrated assessment, water ecosystems, transformation, taxonomic structure, microalgae, cyanobacteria, graphical analysis.

Современные масштабы и мощность антропогенной деятельности, а также глобальные и региональные изменения климата приводят к нарушению устойчивости водных экосистем и ухудшению качества вод. В связи с этим все более актуальными становятся вопросы оценки качества и экологического состояния поверхностных вод, а также их трансформаций под воздействием комплекса природных и антропогенных факторов.

При проведении интегральной оценки трудно переоценить значение биоиндикационных методов, позволяющих по структурным и экологичес-

(C) Беспалова Е.В., 2019 ким характеристикам сообществ организмов, по наличию определенных показательных видов-индикаторов и их численности оценивать степень нарушенности природной системы динамичных биологических связей в водоемах. Отклик сообществ фитопланктона и микрофитобентоса на совокупность сложившихся природных или природно-антропогенных условий (климат, рельеф, эколого-геохимические особенности водосборной поверхности, морфология и морфометрия водоема, гидрохимические показатели водной среды, степень развития высшей водной растительности и их смену) служит важным индикатором состояния 


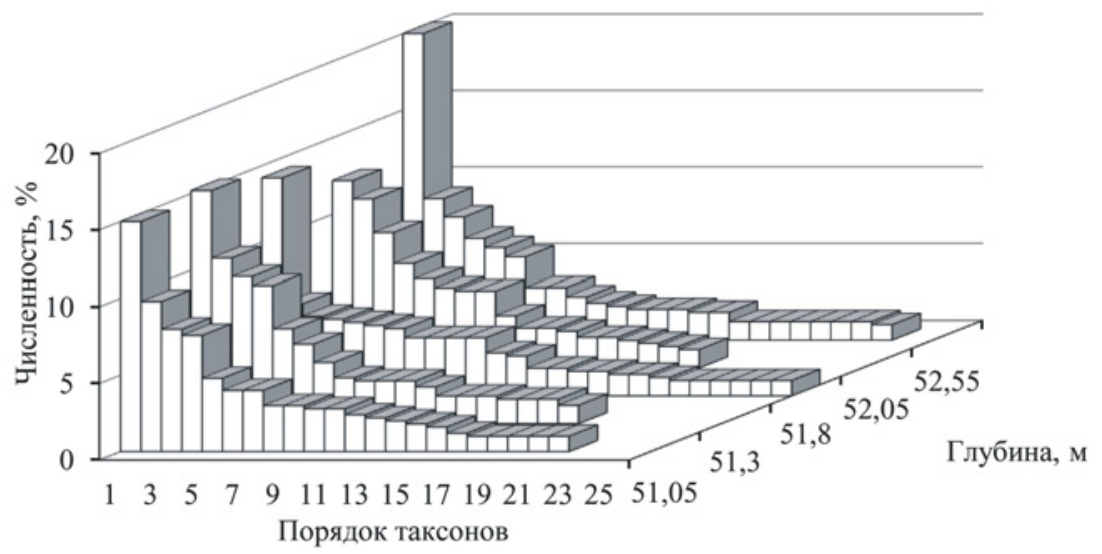

Puc. 1. Таксономическая структура диатомовых комплексов разреза Бибирево на II этапе развития (линейная система координат)

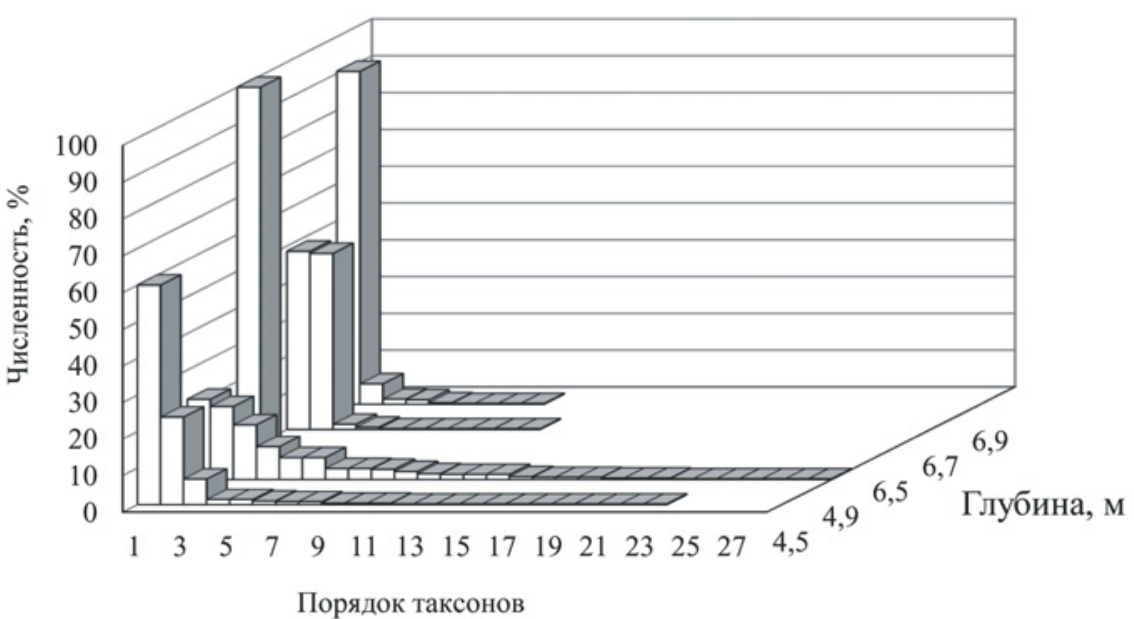

Puc. 2. Таксономическая структура диатомовых комплексов разреза Челсма-22 (линейная система координат)

водной экосистемы, степени ее кризисности $[15$, $16,20]$. Среди гидробионтов-биоиндикаторов широко используются представители фитопланктона и микрофитобентоса, а именно микроскопические водоросли (прежде всего диатомовые) и цианобактерии. Они присутствуют практически во всех водах в качестве доминантов и в системе трофических сетей входят в состав первичных продуцентов.

\section{Методы и материалы}

В практике биоиндикационных исследований применяются различные подходы к оценке экологического состояния водоемов, основанные на анализе фитопланктона и микрофитобентоса: сапробиологический анализ путем расчета значений индекса Пантле-Букка в модификации В. Сладечека и индекса Т. Ватанабе, графо-аналитический метод Г. Кнеппе, графический анализ таксономических пропорций в диатомовых комплексах Л.В. Разумовского и другие $[6,15,18,19]$.
Анализ научной литературы $[18,19]$ и собственные исследования $[8,9,10,11,12]$ показывают большие возможности графического анализа таксономической структуры диатомовых комплексов в оценке состояния водных экосистем. Однако при исследовании современных водоемов, подвергающихся значительной антропогенной нагрузке, нередко возникают ситуации, когда в сообществах микроводорослей не обнаруживаются диатомовые, что ограничивает применение указанного метода. Также необходимы четкие количественные критерии, позволяющие определять переход водной экосистемы из одного состояния в другое при графическом анализе таксономической структуры сообществ фитопланктона и микрофитобентоса. Это обуславливает актуальность научной задачи совершенствования методики интегральной оценки трансформаций водных экосистем, применимой для исследования как природных, так и природ- 
Показатели экологической нормы распределения таксономических пропорций в сообществах фитопланктона и микрофитобентоса

\begin{tabular}{|l|c|c|}
\hline \multicolumn{1}{|c|}{ Показатели } & $\begin{array}{c}\text { Относительная } \\
\text { численность } \\
\text { первого таксона в } \\
\text { ранжированном } \\
\text { ряду }\end{array}$ & $\begin{array}{c}\text { Тип линии тренда и форма гистограмм } \\
\text { распределения таксономических пропорций }\end{array}$ \\
\hline $\begin{array}{l}\text { Водные экосистемы } \\
\text { заповедных территорий }\end{array}$ & до 20\% & \begin{tabular}{c} 
логистический (сигмоидальная форма) \\
\hline $\begin{array}{l}\text { Водные экосистемы, } \\
\text { расположенные вне } \\
\text { заповедных территорий }\end{array}$
\end{tabular} \\
\hline
\end{tabular}

но-антропогенных водоемов, испытывающих различный уровень нагрузки.

Фактическим материалом для исследований послужили: 1) архивные и опубликованные материалы по диатомовой флоре из разрезов древнеозерных отложений: ПольноеЛапино в бассейне Верхнего Дона, Бибирево и Челсма-22 в Ярославско-Костромском Поволжье, Балашиха в бассейне Верхней Оки $[2,3]$; 2) собственные и архивные материалы изучения сообществ микроводорослей и цианобактерий Матырского (за период 20102016 годы) и Воронежского (1988-2016 годы) водохранилищ $[3,4] ; 3)$ архивные и опубликованные материалы изучения сообществ микроводорослей и цианобактерий озер Рамза и Кипец (20072014 годы), расположенных в пределах государственного природного заповедника «Воронинский» [5].

\section{Результаты исследований и их обсуждение}

В основу методики интегральной оценки трансформаций водных экосистем положены выявленные связи между изменением эколого-биологических характеристик и воздействием комплекса природных и природно-антропогенных условий. Ранее проведенные исследования позволили раскрыть закономерности изменения таксономической структуры сообществ фитопланктона и микрофитобентоса неоплейстоценовых и современных водных экосистем в зависимости от смены природных и природно-антропогенных условий через таксономические пропорции при графическом анализе [8, 9].

На примере межледниковых озер показано, что при благоприятных климатических условиях (во время климатического предоптимума и оптимума межледниковья) наблюдаются сигмоидальная и вогнутая форма гистограмм распределения так- сономических пропорций в диатомовых комплексах с пиками развития отельных таксонов микроводорослей до $40 \%$ (рис. 1). Пики более $40 \%$ развития отдельных таксонов, «ломаная линия» и вогнутая форма гистограмм, фиксируются при неблагоприятных природных условиях (позднеледниковье - начало следующего межледниковья или конец межледниковья - начало следующего оледенения) и характеризуют кризисные состояния водных экосистем. Это согласуется с представлениями о ярко выраженных кратковременных климатических флуктуациях, характерных для переходных этапов между ледниковыми и межледниковыми эпохами [17]. Для суровых перигляциальных условий криолитозоны, изученных на примере разреза Челсма-22, характерны пики развития отдельных таксонов микроводорослей свыше 50$60 \%$ (рис. 2).

Исследования озер Рамза и Кипец, Матырского и Воронежского водохранилищ показали, что таксономическая структура сообществ микроводорослей и цианобактерий современных водных экосистем при усилении воздействия природно-антропогенных факторов изменяется сходным образом, как и структура диатомовых комплексов неоплейстоценовых озер при смене климато-ландшафтных обстановок $[8,9,11]$. А именно: логистический тип линии тренда сменяется экспоненциальным, форма гистограмм переходит от сигмоидальной к вогнутой, наблюдаются пики развития 1-2 таксонов. Выявленные закономерности изменения таксономической структуры фитопланктона и микрофитобентоса положены в основу определения экологической нормы распределения таксономических пропорций в сообществах микроводорослей и цианобактерий (таблица 1). При этом учтен дифференцированный подход, при котором 
«для водных объектов заповедных территорий не допустимы никакие экологические модификации; для природных экосистем с умеренной антропогенной нагрузкой и искусственных водоемов не допустимы экологические модификации, ведущие к экологическому регрессу» [1].

Под экологической нормой в работе понимается допустимый диапазон значений параметра, отражающий оптимальное состояние водной экосистемы. Уровни 20 и $40 \%$ совпадают с балльной шкалой оценок обилия микроводорослей и цианобактерий. Численность 20-40\% соответствует 7 баллам («очень часто»), численность 40-100\% 9 баллам («в массе») и характерна для доминирующих форм.

Для природных водоемов заповедных территорий экологической нормой распределения таксономических пропорций в сообществах микроводорослей и цианобактерий является сигмоидальная форма гистограмм (логистический тип линии тренда) с пиками развития отдельных таксонов до $20 \%$. Сходные очертания принимают гистограммы в диатомовых комплексах межледниковых озер при наиболее благоприятных природных условиях. Появление пиков свыше $20 \%$ и переход гистограмм к вогнутым формам (экспоненциальный тип линии тренда) позволили выявить произошедшие природные трансформации озер Рамза и Кипец вследствие аномально высоких летних температур воздуха 2010-2012 годов (рис. 3). При этом наиболее значительные изменения отмечались по озеру Кипец.
Анализ графиков в логарифмической системе координат также подтвердил, что в большей степени изменилась структура фитопланктона и микрофитобентоса в озере Кипец. Результирующая линия 2014 года вышла из единой генерации, что отражает переход водной экосистемы из одной области устойчивости в другую (рис. 3). В целом, перемещение линий в логарифмической системе координат (уменьшение значений показателя степени $\alpha$ ) и по озеру Кипец, и по озеру Рамза свидетельствует об увеличении уровня нагрузки на водоемы заповедника.

Для водных экосистем, расположенных вне особо охраняемых природных территорий, экологической нормой распределения таксономических пропорций в сообществах фитопланктона и микрофитобентосаявляются сигмоидальная и вогнутая (с пропорциональными очертаниями) форма гистограмм с пиками до $40 \%$. Пики выше $40 \%$, а также переход графиков к вогнутой форме (с непропорциональными очертаниями) и форме «ломаной линии», свидетельствуют о крайне сильном воздействии на водоемы, сравнимом с суровыми условиями ледниковой эпохи или переходом от межледниковья к оледенению. Такие признаки зафиксированы в различные годы в таксономической структуре фитопланктона и микрофитобентоса Матырского и Воронежского водохранилищ (рис. 4 и 5). Интенсивное «цветение» вод цианобактериями и их доминирование не только в летнем, но и в весеннем и осеннем циклах, сокращение видового разнообразия микроводорослей, а

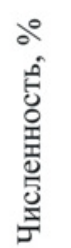

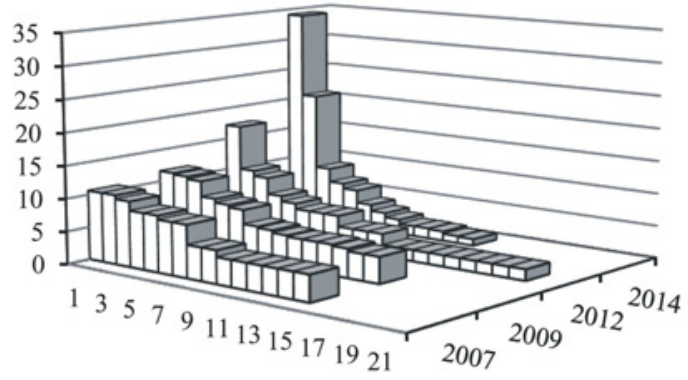

Порядок таксонов

Год

а) линейная система координат

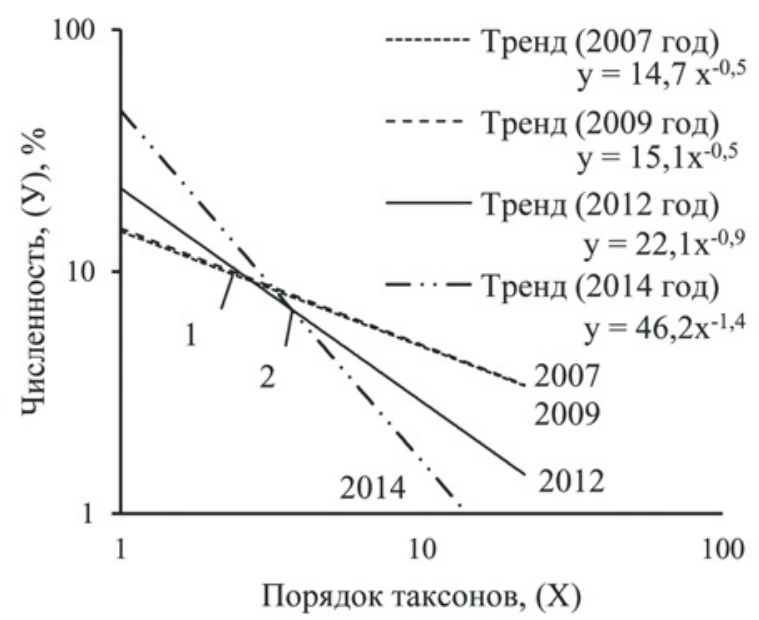

б) логарифмическая система координат

Puc. 3. Таксономическая структура сообществ микроводорослей и цианобактерий озера Кипец (без «хвостов»; $\left.0,81<\mathrm{R}^{2}<0,98\right)$ 


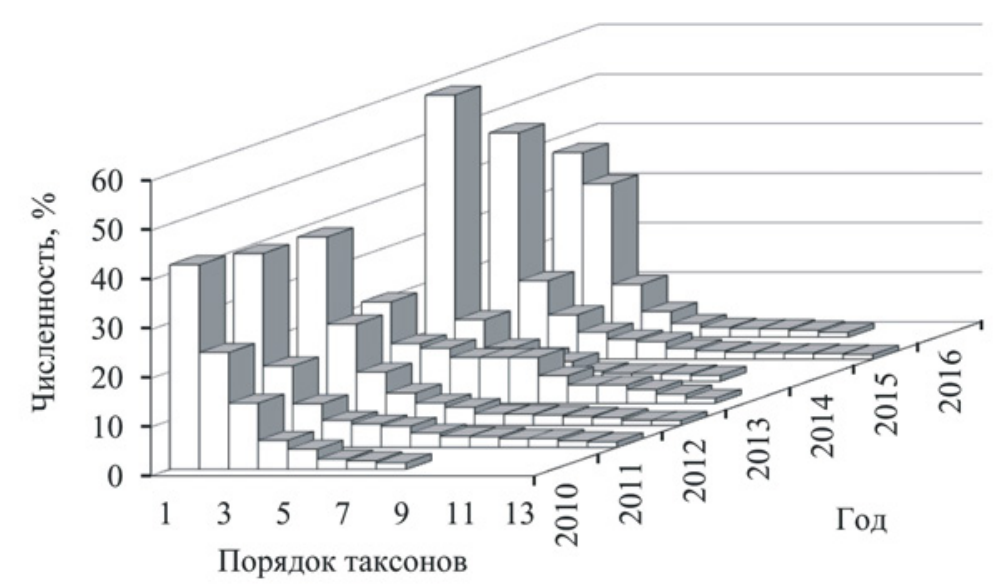

Puc. 4. Таксономическая структура фитопланктона и микрофитобентоса Матырского водохранилища (линейная система координат, без «хвостов»)

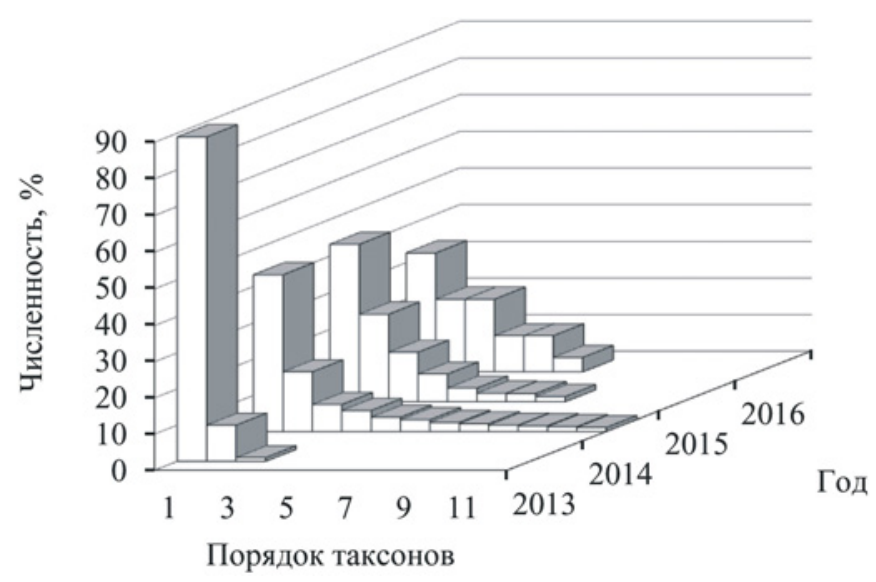

Puc. 5. Таксономическая структура сообществ микроводорослей и цианобактерий Масловского затона Воронежского водохранилища (линейная система координат)

также выбивание линий тренда из общей области пересечения в логарифмической системе координат в отдельные годы [7,9] свидетельствовали о кризисных состояниях изученных водоемов.

Изученные связи между изменением таксономической структуры фитопланктона и микрофитобентоса и воздействием комплекса природных и природно-антропогенных условий положены в основу разработанной методики интегральной геоэкологической оценки трансформаций водных экосистем. Особенностью методики является модернизация метода графического анализа таксономических пропорций. Графические построения для современных водных экосистем предлагается проводить не только по диатомовым, а по всем типам микроводорослей и цианобактериям в связи с периодическим исчезновением диатомей из сообществ под влиянием значительной антропогенной нагрузки. Такой подход позволяет расширить область применения метода, благодаря чему разра- ботанная методика применима для исследования как природных, так и природно-антропогенных водоемов с различным уровнем антропогенной нагрузки. Предложенный нами вариант показал свою состоятельность в исследованиях современных водных экосистем [7, 8, 9, 10, 11, 12]. Данное нововведение не затрагивает водные экосистемы минувших эпох, для которых анализируются только диатомовые комплексы в виду сохранности в древнеозерных отложениях только створок диатомей. Другой стороной модернизации является разработка количественных градаций критериев, отражающих переход водной экосистемы из одного состояния в другое, а также изменение уровня нагрузки на нее. Методика предполагает проведение следующих действий.

1. Отбор проб фитопланктона и микрофитобентоса по стандартным методикам [13].

2. Идентификачия таксономического состава фитопланктона и микрофитобентоса. 
Критерии оценки уровня нагрузки на водную экосистему и ее состояния (экологической модификации по В.А. Абакумову) в линейной системе координат

\begin{tabular}{|c|c|c|c|c|}
\hline \multirow{2}{*}{$\begin{array}{c}\text { Уровень } \\
\text { нагрузки на } \\
\text { водную } \\
\text { экосистему }\end{array}$} & \multirow{2}{*}{$\begin{array}{c}\text { Численность } \\
\text { первого таксона в } \\
\text { ранжированном } \\
\text { ряду, \% }\end{array}$} & \multicolumn{2}{|c|}{$\begin{array}{l}\text { Гистограмма распределения } \\
\text { таксономических пропорций }\end{array}$} & \multirow{2}{*}{$\begin{array}{l}\text { Состояние } \\
\text { водной } \\
\text { экосистемы }\end{array}$} \\
\hline & & Тип линии тренда & $\begin{array}{c}\text { Форма } \\
\text { гистограммы }\end{array}$ & \\
\hline Низкий & $<20$ & $\begin{array}{l}\text { логистический } \\
Y=\frac{\alpha}{1+e^{b(x-x 0)}}+c\end{array}$ & $\begin{array}{c}\text { сигмоидальная } \\
\text { (выпукло- } \\
\text { вогнутая) }\end{array}$ & $\begin{array}{l}\text { «фоновое } \\
\text { состояние» }\end{array}$ \\
\hline \multirow[b]{2}{*}{ Средний } & \multirow[b]{2}{*}{$20-40$} & логистический & сигмоидальная & \multirow[b]{2}{*}{$\begin{array}{c}\text { «экологическое } \\
\text { напряжение» }\end{array}$} \\
\hline & & $\begin{array}{c}\text { экспоненциальный с } \\
\text { малым показателем } \\
\text { экспоненты } \\
\left(Y=a e^{-b x}, b<1\right)\end{array}$ & вогнутая & \\
\hline Высокий & $40-80$ & $\begin{array}{c}\text { экспоненциальный с } \\
\text { большим } \\
\text { показателем } \\
\text { экспоненты }(b>1)\end{array}$ & $\begin{array}{c}\text { вогнутая и } \\
\text { «ломаная линия» }\end{array}$ & $\begin{array}{l}\text { «экологический } \\
\text { регресс» }\end{array}$ \\
\hline
\end{tabular}

3. Построение графиков, отражающих таксономическую структуру фитопланктона и микрофитобентоса. Для этого определяется относительная численность всех идентифицированных таксонов видового и более низкого рангов (форм и разновидностей) для каждого комплекса, отобранного в конкретном пункте наблюдения. Объем выборки должен быть репрезентативным ( $\geq 200$ клеток (колоний) при низком разнообразии, в остальных случаях 500 клеток (колоний) в пробе). Желательно, чтобы выборки были одинаковы и сопоставимы по объему. Выборки ранжируются по величине относительной численности таксонов от максимальной к минимальной. Рассчитывается результирующая путем осреднения нескольких ранжированных выборок, что позволяет абстрагироваться от короткопериодных флуктуаций. Далее строятся гистограммы распределения таксономических пропорций: по оси абсцисс откладывается порядковый номер таксона в ранжированном ряду, а по оси ординат - его относительная численность в \%. Линии строятся двумя способами: с учетом всего спектра таксонов и без учета таксонов с численностью ниже $1 \%$ (без «хвоста» гистограммы). Анализ полученных графиков ведется в линейной и логарифмической системах координат, при этом в последней анализируются не сами графики, а их степенные тренды [18]. Описание основных моделей соотношения численностей таксонов в сообществе приведено в работах Н. В. Лебедовой и
Д. А. Криволуцкого, В. К. Шитикова и Г. С. Розенберга $[14,20]$. В связи с тем, что биологические процессы «не всегда совпадают с идеальными вариантами, представленными в абстрактном математическом пространстве» [18], для описания гистограмм распределения таксономических пропорций используются такие характеристики, как очертания (пропорциональные, «выровненные»), формы (сигмоидальная, вогнутая, «ломаная линия»), тип распределения линии тренда (логистический, экспоненциальный). Для определения значений последнего критерия для каждой гистограммы подбираются различные тренды для оценки сходства наблюдаемого распределения таксономических пропорций в сообществе с теоретической функцией. Для оценки статистической достоверности графических построений рассчитывается коэффициент детерминации $\left(\mathrm{R}^{2}\right)$.

4. Оиенка состояния водной экосистемы и уровня нагрузки на нее.

Проведенные исследования позволили количественно определить пороговые величины показателей водной экосистемы, отражающие ее переход из одного состояния в другое, а также изменение уровня нагрузки на нее. При графическом анализе в линейной системе координат критериями оценки являются: 1) относительная численность первого таксона в ранжированном ряду; 2) тип линии тренда и форма гистограмм. Разработанная шкала оценочных критериев в линейной системе 
Критерии оценки уровня нагрузки на водную экосистему и ее состояния (экологической модификации по В.А. Абакумову) в логарифмической системе координат

\begin{tabular}{|l|c|l|}
\hline $\begin{array}{c}\text { Уровень нагрузки на } \\
\text { водную экосистему }\end{array}$ & $\begin{array}{c}\text { Значение } \alpha-\text { показателя степенной } \\
\text { функции (тренда) }\end{array}$ & Состояние водной экосистемы \\
\hline Низкий & $\alpha \geq-1,0$ & «фоновое состояние» \\
\hline Средний & $-1,5 \leq \alpha<-1,0$ & «экологическое напряжение» \\
\hline Высокий & $-3,0 \leq \alpha<-1,5$ & \multirow{2}{*}{ «экологический регресс» } \\
\cline { 1 - 2 } Очень высокий & $\alpha<-3,0$ & \multirow{2}{*}{} \\
\cline { 1 - 2 }
\end{tabular}

Критерии выделения в акватории природно-антропогенных водных экосистем участков различной экологической напряженности

\begin{tabular}{|c|c|c|c|}
\hline $\begin{array}{c}\text { Тип участка и } \\
\text { степень } \\
\text { экологической } \\
\text { напряженности }\end{array}$ & $\begin{array}{c}\text { Относительная } \\
\text { численность } \\
\text { первого } \\
\text { таксона в } \\
\text { ранжированном } \\
\text { ряду } \\
\end{array}$ & $\begin{array}{c}\text { Тип линии тренда } \\
\text { (форма) гистограмм } \\
\text { распределения } \\
\text { таксономических } \\
\text { пропорций }\end{array}$ & $\begin{array}{c}\text { Преобладающая } \\
\text { в течение } \\
\text { вегетационного сезона } \\
\text { группа (диатомовые } \\
\text { водоросли или } \\
\text { цианобактерии) } \\
\end{array}$ \\
\hline $\begin{array}{l}\text { 1. «экологическое } \\
\text { напряжение» }\end{array}$ & $20-40 \%$ & $\begin{array}{l}\text { логистический } \\
\text { (сигмоидальная), } \\
\text { экспоненциальный с малым } \\
\text { показателем экспоненты } \\
\text { (вогнутая) }\end{array}$ & $\begin{array}{l}\text { равные пропорции, } \\
\text { цианобактерии или } \\
\text { диатомовые }\end{array}$ \\
\hline $\begin{array}{l}\text { 2. переход к } \\
\text { «экологическому } \\
\text { регрессу» }\end{array}$ & \multirow[t]{2}{*}{$>40 \%$} & \multirow{2}{*}{$\begin{array}{l}\text { экспоненциальный с } \\
\text { большим показателем } \\
\text { экспоненты (вогнутая, } \\
\text { «ломаная линия») }\end{array}$} & $\begin{array}{l}\text { равные пропорции или } \\
\text { диатомовые водоросли }\end{array}$ \\
\hline $\begin{array}{l}\text { 3. «экологический } \\
\text { регресс» }\end{array}$ & & & цианобактерии \\
\hline
\end{tabular}

координат представлена в таблице 2. Состояния водной экосистемы соотнесены с экологическими модификациями по В. А. Абакумову [1].

Дополнительно проводится анализ в логарифмической системе координат, в которой зависимость между $\mathrm{X}$ и $\mathrm{Y}$ принимает вид функции $Y=k x^{\alpha}$ с отрицательным показателем степени $\alpha$. Угол наклона линии зависит от уровня нагрузки на водоем: при его усилении показатель степени уменьшается. Разработанная шкала оценочных критериев в логарифмической системе координат представлена в таблице 3 .

Для водоемов особо охраняемых природных территорий допустим низкий уровень нагрузки, что соответствует фоновому состоянию экосистемы. Для водоемов, расположенных вне особо охраняемых природных территорий, допустим средний уровень нагрузки. При превышении нормы рекомендуется снижение антропогенной нагрузки.

5. Проведение экологического районирования акваторий водных экосистем, части которых ис- пытылвают различную антропогенную нагрузку. Участки различной экологической напряженности выделяются по критериям, отражающим таксономическую структуру и состав сообществ фитопланктона и микрофитобентоса (таблица 4). Названия типов участков соотнесены с терминами экологических модификаций по В. А. Абакумову [1].

6. Выявление критических переходов в развитии водной экосистемы. Графический анализ таксономической структуры фитопланктона и микрофитобентоса является информативной основой определения смен областей устойчивости в развитии экосистемы. Критические переходы выявляются по изменению гистограмм распределения таксономических пропорций в линейной системе координат (резкое появление пиков развития отдельных таксонов, смена формы гистограммы и типа линии тренда), по взаимному расположению степенных трендов в логарифмической системе координат. Если степенные тренды образуют генерацию с единым центром пересечения, значит 


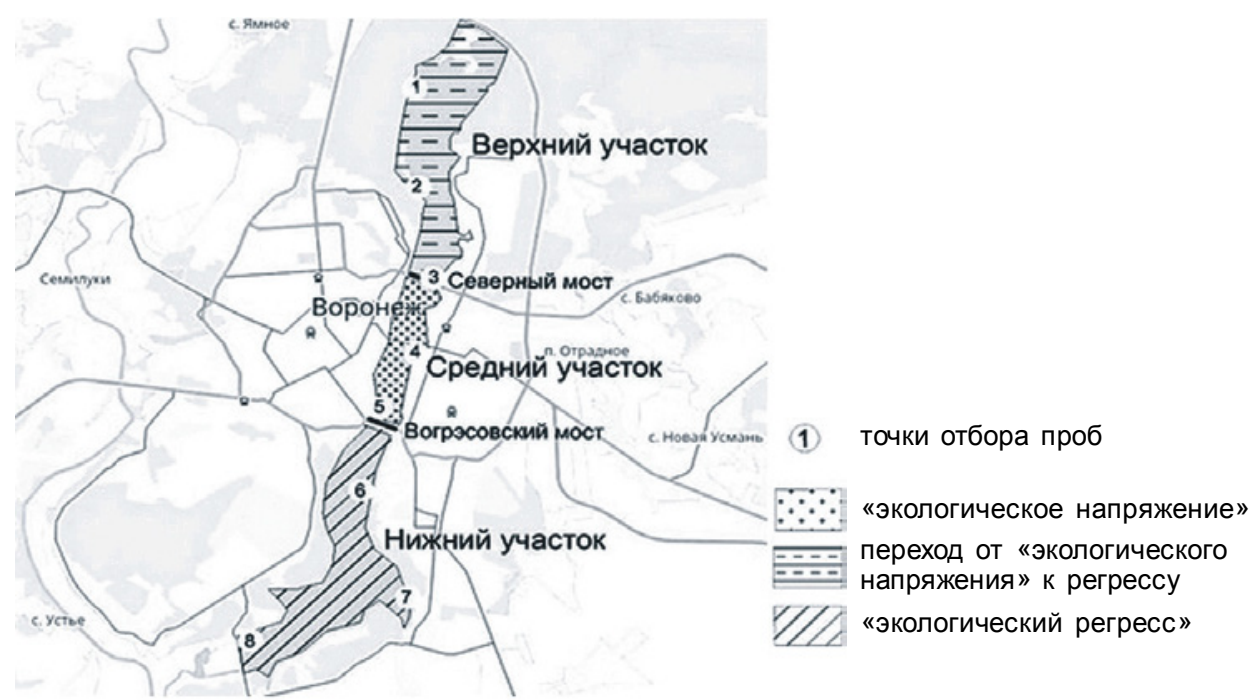

Puc. 6. Схема районирования акватории Воронежского водохранилища

экосистема находится в одной области устойчивости. Выбивание тренда из генерации символизирует критическую точку в развитии экосистемы, находящейся на грани фазового перехода [18]. Далее экосистема может либо вернуться в исходное состояние при уменьшении уровня нагрузки, либо перейти в новую область устойчивости при сохранении или увеличении силы нагрузки. Смена доминирующих таксонов также свидетельствует об изменениях в экосистеме.

7. Для выявления природных причин трансформаций водных экосистем рассчитываются ранговые коэффициенты корреляции между относительной численностью первого таксона в ранжированном ряду и климатическими параметрами. Наиболее информативными показателями являются среднемесячные температуры и ежемесячное количество выпавших осадков в течение вегетационного сезона.

8. Для выявления антропогенных причин трансформаций рассчитываются ранговые коэффициенты корреляции между относительной численностью первого таксона в ранжированном ряду и гидрохимическими показателями. Обязательно осуществляется инвентаризация антропогенных источников загрязнения и путей поступления поллютантов в водоем.

9. Для определения класса качества и уровня загрязнения вод, обратимости антропогенных преобразований, происходящих в водоеме, проводится сапробиологический анализ путем расчета значений индекса сапробности Пантле-Букка в модификации В. Сладечека и индекса Т. Ватанабе [6, 15]. Отмечается наличие видов-индикаторов заг- рязненных местообитаний (их распространение свыше 50 \% является признаком сильного загрязнения).

На основе разработанной методики нами было проведено районирование акватории Воронежского водохранилища с выделением трех участков различной экологической напряженности (рис. 6).

Ситуация в Нижнем участке характерна для «экологического регресса», в Верхнем наблюдается промежуточное положение между «экологическим напряжением» и «экологическим регрессом», в Среднем участке - «экологическое напряжение» за счет проявления экотонных свойств [7]. Ситуация в Нижнем участке рассматривается как предполагаемый сценарий неблагоприятного развития водохранилища.

Таким образом, разработанная методика позволяет точнее проводить оценку состояния водной экосистемы и уровня нагрузки на нее, выявлять трансформации и возможные (природные и антропогенные) причины изменений, а также районировать акватории природно-антропогенных водоемов.

\section{Заключение}

Исследование неоплейстоценовых и современных водных экосистем центра Восточно-Европейской равнины позволили выявить закономерности изменения таксономических пропорций в сообществах фитопланктона и микрофитобентоса при смене природных и природно-антропогенных условий и определить параметры экологической нормы их распределения. Показано, чем более нестабильны и суровы условия, в которых развивается озеро, тем чаще наблюдается сверхдомини- 
рование 1-2 таксонов, тем выше пики и более непропорциональные очертания принимает гистограмма распределения таксономических пропорций, тем меньшие значения принимает показатель степенной функции на графиках в логарифмической системе координат.

Выявленные связи между изменением эколого-биологических характеристик и природным и природно-антропогенным воздействием положены в основу разработанной методики интегральной оценки трансформаций водных экосистем. Отличительной особенностью методики является модернизация метода графического анализа таксономической структуры фитопланктона и микрофитобентоса путем учета всех типов микроводорослей и цианобактерий в современных водных экосистемах, что позволяет расширить область его применения. Разработаны количественные градации критериев, позволяющие оценивать состояние и уровень нагрузки на водные экосистемы, выявлять критические переходы в их развитии, а также проводить районирование акваторий природно-антропогенных водоемов.

В методике интегрированы различные методы исследований, в том числе графический, который апробирован в разных климатических и ландшафтных обстановках, а также при смене географических зон в течение межледниковий неоплейстоцена. Это показывает широкую область применения разработанной методики. Она может использоваться для дальнейшего исследования водоемов центра Восточно-Европейской равнины и других регионов.

\section{СПИСОК ЛИТЕРАТУРЫ}

1. Абакумов В. А. К методу контроля экологических модификаций фитоценозов / В. А. Абакумов, Л. А. Сиренко // Научные основы биомониторинга пресноводных экосистем : труды советско-французского симпозиума. - Ленинград : Гидрометиздат, 1988. C. 117-131.

2. Анциферова Г. А. Межледниковые озера центра Восточно-Европейской равнины. Палеоэкология, осадконакопление и эволюция диатомовой флоры / Г. А. Анциферова. - Саарбрюккен : Palmarium Academic Publishing, 2014. - $362 \mathrm{c}$.

3. Анциферова Г. А. Эволюция диатомовой флоры и межледникового осадконакопления центра ВосточноЕвропейской равнины / Г. А. Анциферова. - Воронеж, 2001. - 198 с. - (Труды научно-исследовательского института геологии Воронежского государственного университета; Вып. 2).

4. Анциферова Г. А. Состояние водной среды Воронежского водохранилища в связи с экологической ситуацией в Масловском затоне / Г. А. Анциферова, Е. В. Беспалова // Вестник Воронежского государственного университета. Сер. География. Геоэкология. - 2016. - № 2. - С. 91-100.

5. Анциферова Г. А. Долгосрочные последствия влияния аномальных высоких летних температур воздуха 2010-2012 годов на водные экосистемы лесостепной зоны / Г. А. Анциферова, Н. И. Русова // Вестник Воронежского государственного университета. Сер. География. Геоэкология. - 2017. - № 2. - С. 5-12.

6. Баринова С. С. Метод Ватанабе в оценке органического загрязнения вод / С. С. Баринова, Л. А. Медведева // Альгология. - 1998. - Т. 8, № 4. - С. 428-448.

7. Беспалова Е. В. Геоэкологический мониторинг Воронежского водохранилища и прилегающей территории / Е. В. Беспалова // Вода: химия и экология. 2017. - № 9. - С. 28-36.

8. Беспалова Е. В. Графический анализ структуры комплексов микроводорослей межледниковых и современных водных экосистем центра Восточно-Европейской равнины / Е. В. Беспалова // Вестник Воронежского государственного университета. Сер. География. Геоэкология. - 2017. - № 2. - С.13-20.

9. Беспалова Е. В. Оценка состояния водных экосистем Центрального Черноземья на основе анализа структурных перестроек комплексов микроводорослей и цианобактерий / Е. В. Беспалова // Проблемы экологического мониторинга и моделирования экосистем. 2017. - № 3. - С. 84-95.

10. Беспалова Е. В. Оценка эколого-биологического качества водной среды Воронежского водохранилища / Е. В. Беспалова // Комплексные проблемы техносферной безопасности : материалы Международной научно-практической конференции. - Воронеж, 2016. Ч. VI. - C. 90-95.

11. Беспалова Е. В. Структурные перестройки комплексов микроводорослей в озерах Рамза и Кипец / Е. В. Беспалова // Биологическое разнообразие - основа устойчивого развития : материалы Международной научно-практической конференции. - Махачкала, 2017. - C. 96-101.

12. Беспалова Е. В. Характеристика видовой структуры и оценка качества вод Воронежского водохранилища / Е. В. Беспалова // Комплексные проблемы техносферной безопасности. Безопасный город : материалы XI научно-практической конференции. - Воронеж, 2015. - Ч. I. - С. 197-202.

13. Временные методические указания гидрометеорологическим станциям и постам по отбору, подготовке проб воды и грунта на химический и гидробиологический анализ и проведение анализа первого дня. - Москва : Гидрометеоиздат, 1983. - 27 с.

14. Лебедева Н. В. Биологическое разнообразие и методы его оценки / Н. В. Лебедева, Д. А. Криволуцкий // География и мониторинг биоразнообразия. - Москва : Научный и учебно-методический центр, 2002. C. 9-142. 
15. Макрушин А. В. Биологический анализ качества вод / А. В. Макрушин. - Ленинград : Зоологический институт АН СССР, 1974. - 60 с.

16. Методика изучения биоценозов внутренних водоемов / ред. Ф. Д. Мордухай-Болтовский. - Москва : Наука, 1975. - 240 с.

17. Новенко Е. Ю. Изменения растительности и климата Центральной и Восточной Европы в позднем плейстоцене и голоцене в межледниковые и переходные этапы климатических макроциклов / Е. Ю. Новенко. - Москва : ГЕОС, 2016. - 228 с.

18. Разумовский Л. В. Оценка трансформации озерных экосистем методом диатомового анализа / Л. В. Разумовский. - Москва : ГЕОС, 2012. - 199 с.

19. Разумовский Л. В. Долговременные трансформации диатомовых комплексов в озерах Борое и Глубокое / Л. В. Разумовский, М. А. Гололобова // Вестник Московского университета. Сер. 16, Биология. - 2014. - № 1. - С. 19-23.

20. Шитиков В. К. Оценка биоразнообразия: попытка формального обобщения / В. К. Шитиков, Г. С. Розенберг // Количественные методы экологии и гидробиологии : сборник научных трудов, посвященный памяти А. И. Баканова / под ред. Г. С. Розенберга. - Тольятти : Самарский научный центр РАН, 2005. - С. 91-129.

\section{REFERENCES}

1. Abakumov V. A. K metodu kontrolya ekologicheskikh modifikatsiy fitotsenozov / V. A. Abakumov, L. A. Sirenko // Nauchnyye osnovy biomonitoringa presnovodnykh ekosistem : trudy sovetsko-frantsuzskogo simpoziuma. - Leningrad : Gidrometizdat, 1988. - S. 117-131.

2. Antsiferova G. A. Mezhlednikovyye ozera tsentra Vostochno-Evropeyskoy ravniny. Paleoekologiya, osadkonakopleniye i evolyutsiya diatomovoy flory / G. A. Antsiferova. - Saarbryukken : Palmarium Academic Publishing, 2014. - 362 s.

3. Antsiferova G. A. Evolyutsiya diatomovoy flory i mezhlednikovogo osadkonakopleniya tsentra VostochnoEvropeyskoy ravniny / G. A. Antsiferova. - Voronezh, 2001. - 198 s. - (Trudy nauchno-issledovatel'skogo instituta geologii Voronezhskogo gosudarstvennogo universiteta; Vyp. 2).

4. Antsiferova G. A. Sostoyaniye vodnoy sredy Voronezhskogo vodokhranilishcha v svyazi s ekologicheskoy situatsiyey v Maslovskom zatone / G. A. Antsiferova, E. V. Bespalova// Vestnik Voronezhskogo gosudarstvennogo universiteta. Ser. Geografiya. Geoekologiya. - 2016. № 2. - S. 91-100.

5. Antsiferova G. A. Dolgosrochnyye posledstviya vliyaniya anomal'nykh vysokikh letnikh temperatur vozdukha 2010-2012 godov na vodnyye ekosistemy lesostepnoy zony / G. A. Antsiferova, N. I. Rusova // Vestnik Voronezhskogo gosudarstvennogo universiteta. Ser. Geografiya. Geoekologiya. - 2017. - № 2. - S. 5-12.

6. Barinova S. S. Metod Vatanabe v otsenke organicheskogo zagryazneniya vod / S. S. Barinova,
L. A. Medvedeva // Al'gologiya. - 1998. - T. 8, № 4. S. 428-448.

7. Bespalova E. V. Geoekologicheskiy monitoring Voronezhskogo vodokhranilishcha i prilegayushchey territorii / E. V. Bespalova // Voda: khimiya i ekologiya. - 2017. № 9. - S. 28-36.

8. Bespalova E. V. Graficheskiy analiz struktury kompleksov mikrovodorosley mezhlednikovykh i sovremennykh vodnykh ekosistem tsentra Vostochno-Evropeyskoy ravniny / E. V. Bespalova // Vestnik Voronezhskogo gosudarstvennogo universiteta. Ser. Geografiya. Geoekologiya. 2017. - № 2. - S.13-20.

9. Bespalova E. V. Otsenka sostoyaniya vodnykh ekosistem TSentral'nogo CHernozem'ya na osnove analiza strukturnykh perestroyek kompleksov mikrovodorosley i tsianobakteriy / E. V. Bespalova // Problemy ekologicheskogo monitoringa i modelirovaniya ekosistem. - 2017. - № 3. - S. 84-95.

10. Bespalova E. V. Otsenka ekologo-biologicheskogo kachestva vodnoy sredy Voronezhskogo vodokhranilishcha / E. V. Bespalova // Kompleksnyye problemy tekhnosfernoy bezopasnosti : materialy Mezhdunarodnoy nauchnoprakticheskoy konferentsii. - Voronezh, 2016. - CH. VI. S. 90-95.

11. Bespalova E. V. Strukturnyye perestroyki kompleksov mikrovodorosley v ozerakh Ramza i Kipets / E. V. Bespalova // Biologicheskoye raznoobraziye - osnova ustoychivogo razvitiya : materialy Mezhdunarodnoy nauchno-prakticheskoy konferentsii. - Makhachkala, 2017. - S. 96-101.

12. Bespalova E. V. KHarakteristika vidovoy struktury i otsenka kachestva vod Voronezhskogo vodokhranilishcha / E. V. Bespalova // Kompleksnyye problemy tekhnosfernoy bezopasnosti. Bezopasnyy gorod : materialy XI nauchno-prakticheskoy konferentsii. - Voronezh, 2015. - CH. I. - S. 197-202.

13. Vremennyye metodicheskiye ukazaniya gidrometeorologicheskim stantsiyam i postam po otboru, podgotovke prob vody i grunta na khimicheskiy i gidrobiologicheskiy analiz i provedeniye analiza pervogo dnya. Moskva : Gidrometeoizdat, 1983. - 27 s.

14. Lebedeva N. V. Biologicheskoye raznoobraziye i metody ego otsenki / N. V. Lebedeva, D. A. Krivolutskiy // Geografiya i monitoring bioraznoobraziya. - Moskva : Nauchnyy i uchebno-metodicheskiy tsentr, 2002. - S. 9-142.

15. Makrushin A. V. Biologicheskiy analiz kachestva vod / A. V. Makrushin. - Leningrad : Zoologicheskiy institut AN SSSR, 1974. - $60 \mathrm{~s}$.

16. Metodika izucheniya biotsenozov vnutrennikh vodoyemov / red. F. D. Mordukhay-Boltovskiy. - Moskva : Nauka, 1975. - $240 \mathrm{~s}$.

17. Novenko E. YU. Izmeneniya rastitel'nosti i klimata TSentral'noy i Vostochnoy Evropy v pozdnem pleystotsene i golotsene $\mathrm{v}$ mezhlednikovyye i perekhodnyye etapy klimaticheskikh makrotsiklov / E. YU. Novenko. - Moskva : GEOS, 2016. - $228 \mathrm{~s}$. 


\section{Е.В. Беспалова}

18. Razumovskiy L. V. Otsenka transformatsii ozernykh ekosistem metodom diatomovogo analiza / L. V. Razumovskiy. - Moskva : GEOS, 2012. - 199 s.

19. Razumovskiy L. V. Dolgovremennyye transformatsii diatomovykh kompleksov v ozerakh Boroye i Glubokoye / L. V. Razumovskiy, M. A. Gololobova // Vestnik Moskovskogo universiteta. Ser. 16, Biologiya. - 2014. - № 1. S. 19-23.

Беспалова Елена Владимировна

кандидат географических наук, Воронежский государственный университет, г. Воронеж, т. (473) 266-56-54, E-mail: elena bespalova@bk.ru
20. SHitikov V. K. Otsenka bioraznoobraziya: popytka formal'nogo obobshcheniya / V. K. SHitikov, G. S. Rozenberg // Kolichestvennyye metody ekologii i gidrobiologii : sbornik nauchnykh trudov, posvyashchennyy pamyati A. I. Bakanova / pod red. G. S. Rozenberga. - Tol'yatti : Samarskiy nauchnyy tsentr RAN, 2005. - S. 91-129.

Bespalova Elena Vladimirovna

Candidate of Geographical Sciences, Voronezh State University, Voronezh, tel. (473) 266-56-54, E-mail: elena bespalova@bk.ru 